Maria Midura

\title{
PRZYPADKOWOŚĆ ŚMIERCI (WYBRANE ASPEKTY)
}

\begin{abstract}
Nie istnieje coś takiego jak naturalna śmierć; nic z tego, co przydarza się człowiekowi, nie jest naturalne, gdyż sama jego obecność stanowi wyzwanie wobec świata. Wszyscy ludzie musza umrzeć, niemniej dla każdego człowieka jego własna śmierć jest ewenementem; nawet jeśli wie on o jej nieuchronności i pogodzit się z nia, śmierć zawsze jest bezprawnym gwattem ${ }^{1}$.
\end{abstract}

Simone de Beauvoir

1. WSTĘP

Omawiając zjawisko śmierci przypadkowej, należy odwołać się do korzeni myśli Zachodu. Jednym z jej istotnych źródeł jest kultura Starożytnej Grecji, w której przypadek był rozumiany jako

${ }^{1}$ "There is no such thing as a natural death: nothing that happens to a man is ever natural, since his presence calls the world into question. All men must die: but for every man his death is an accident and, even if he knows it and consents to it, an unjustifiable violation": S. de Beauvoir, A Very Easy Death, transl. Patric O'Brian, A. Deutsch \& Weidenfeld \& Nicolson, London 1966, s. 106. 
ślepy los, fatum ${ }^{2}$. Terminy te należy rozumieć w tym kontekście jako przeznaczenie, któremu poddany jest każdy aspekt życia człowieka, nie wyłączając śmierci. W początkowej fazie religii greckiej opozycja świata bogów i ludzi była tożsama z dualizmem nieśmiertelności i śmierci. W związku z tym człowiek w pewnym sensie od urodzenia był skazany na śmierć, która stanowiła jego przeznaczenie.

Kolejną z inspiracji, którą należy podkreślić, są poglądy średniowiecznej Europy, według których śmierć nagła, określana jako mors repentina, była czymś wstydliwym i niegodziwym. Nie mówiło się o niej, a po dopełnieniu pochówku ciała nie wspominało się zmarłego ${ }^{3}$.

Dzisiaj, kiedy śmierć wycofała się z życia publicznego, jej przypadkowość jest raczej czymś poruszającym, a czasami skandalizującym. Jest wydarzeniem, które prowokuje, aby o niej mówić zamiast milczeć. Jest raczej zaprzeczeniem niż potwierdzeniem konieczności, jak głosiła myśl grecka. Obecnie, tak jak w średniowieczu, śmierć przypadkowa to śmierć nagła, nieoczekiwana. Wydaje się ona czymś irracjonalnym, wobec czego rozum nie daje wystarczających wyjaśnień. W czasach nowożytnych przypadkowa śmierć nabrała wielu znaczeń, co sprawiło, iż trudniej jest ją ująć w wąskie ramy jednoznacznej interpretacji. Mówiąc o śmierci, oprócz wymienionych powyżej terminów, należy wziąć pod uwagę także śmierć gwałtowną, spowodowaną przez niefortunny zbieg okoliczności czy niedopełnienie koniecznych obowiązków.

${ }^{2}$ Uosobieniem tak rozumianego przypadku była bogini Tyche przedstawiana często z zawiązanymi oczami. Zob. P. Grimal, Stownik mitologii greckiej i rzymskiej, Ossolineum, Wrocław 1990, s. 354.

${ }^{3}$ Zob. P. Ariès, Człowiek i śmierć, przeł. E. Bąkowska, Państwowy Instytut Wydawniczy, Warszawa 1989, s. 24. 
Niniejszy artykuł składa się z trzech części. W pierwszej z nich omówione zostanie zjawisko przypadkowości śmierci w wierzeniach wybranych kultur pierwotnych, w których śmierć rozumiana jest jako przypadkowe zepsucie idealnego stanu rzeczy lub nieprzewidziana konsekwencja pewnych czynów. Następnie omówiona zostanie przypadkowość śmierci w dziedzinie medycyny, kiedy nieoczekiwany zgon pacjenta pociąga za sobą wiele ważkich i niejednoznacznych konsekwencji. Na koniec poruszony zostanie temat sposobu przedstawiania przypadkowości śmierci w środkach masowego przekazu oraz wpływu mediów na sposób postrzegania naturalnej śmierci przez odbiorców. Te trzy sposoby ujęcia przypadkowości śmierci mają na celu odtworzenie kolejno: genezy, recepcji i interpretacji tego, czym jest „nieprzewidziana” śmierć.

2. PRZYPADKOWOŚĆ ŚMIERCI WEDEUG WIERZEŃ WYBRANYCH KULTUR TRADYCYJNYCH

W przeciwieństwie do poglądów Starożytnej Grecji, w wielu kulturach tradycyjnych śmierć nie jest od początku wpisana w ludzką egzystencję, ale pojawia się w wyniku nieprzewidzianych zdarzeń.

W społeczeństwach tradycyjnych śmierć rozumiana jest jako przypadkowe zepsucie idealnego stanu rzeczy lub jako niespodziewana konsekwencja pewnych czynów. Śmierć pojawia się w sposób wręcz banalny. Jak zauważa Ireneusz Ziemiński:

\footnotetext{
[...] na początku człowiek nie był istotą śmiertelną ani nieśmiertelną, mając możliwość zarówno śmierci, jak i życia bez końca. Mógł zatem nie umierać, pod warunkiem jednak, że nie zaprze-
} 
paści szansy nieśmiertelności; niestety okazja ta została stracona na zawsze $e^{4}$.

Śmierć jest zatem efektem błędu człowieka, zwierzęcia czy nieprzychylności natury lub zbiegu okoliczności. Oto kilka przykładów.

Według jednego z afrykańskich plemion, śmierć pojawiła się przez lekkomyślne działanie człowieka. Pająk,

reprezentant ludzi, obiecał śmierci, która dotychczas polowała w buszu tylko na zwierzęta, w czasie głodu swoją córkę za żonę. Otrzymał w zamian kawałki mięsa, niestety okazało się, że ze swego zabitego dziecka. Rozwścieczony pająk rzucił swą wyostrzoną maczetę w śmierć, którą jednak tylko zranił. Śmierć, ścigając go, odnalazła osiedla ludzkie 5 .

Według wierzeń ludu Aranda, utrata nieśmiertelności nastąpiła na skutek działania sił natury. W wyniku oddzielenia nieba i ziemi, ludziom zaczęło brakować boskiego pokarmu dającego nieśmiertelność, czego efektem była śmierć 6 .

Jeszcze innym przykładem przypadkowości śmierci jest opowieść Arapeszów (ludu Nowej Gwinei) o tym, że śmierć pojawiła się niespodziewanie za sprawą zwierząt. Głosi ona, iż w praczasie ani zwierzęta, ani ludzie nie umierali, ale podobnie jak wąż „zrzucali z siebie skórę i przywdziewali nową, młodą i znowu stawali się młodymi osobnikami"". Nie podobało się to jednak wężowi

${ }^{4}$ I. Ziemiński, Metafizyka śmierci, Wydawnictwo WAM, Kraków 2010, s. 161.

${ }^{5}$ F.M. Rosiński, Stosunek społeczeństw pierwotnych do śmierci, [w:] Problemy współczesnej tanatologii, t. 4, red. J. Kolbuszewski, Wrocławskie Towarzystwo Naukowe, Wrocław 2000, s. 211.

${ }^{6}$ Zob. M. Eliade, Religie australijskie: wprowadzenie, przeł. E. i W. Łagodzcy, Wydawnictwo KR, Warszawa 2004, s. 27, 29.

${ }^{7}$ W. Bęben, Obrzędy przejścia u Arapeszów, Warszawa 1986, s. 155-156 (praca doktorska niepublikowana, obroniona na UW). 
i szczurowi, które postanowiły umrzeć. W momencie, w którym drugiemu ze zwierząt się to udało, na świecie pojawiła się śmierć, a ludzie stali się śmiertelni.

We wszystkich tych sytuacjach pojawienie się śmierci, elementu chaosu, jest poniekąd cezurą, która oddziela mityczny praczas ${ }^{8}$ od czasu historycznego, w którym człowiek staje się śmiertelny. od tego momentu człowiek za pomocą obrzędów, które mają być odwzorowaniem mitycznych wydarzeń, próbuje pokonać chaos i uobecnić wydarzenia z illo tempores do którego odeszli ci, którzy umarli. Kultury tradycyjne posługują się bowiem cykliczną koncepcją czasu, która - w przeciwieństwie do koncepcji czasu historycznego - opiera się na regularnie powtarzających się okresach narodzin i śmierci, powstawania i ginięcia.

Człowiek zachowuje pamięć o swych przodkach, którzy odwiedzają ludzi w marzeniach i snach. Odtwarzanie rytuałów jest również podtrzymywaniem pamięci o zmarłych, a także praktyką, która ma powstrzymać niekorzystne działanie złych duchów. Obecnie, w kulturach tradycyjnych przez analogię do wydarzenia in illo tempore śmierć jest uważana za konsekwencję złych czarów lub działania złych duchów. Jak można przeczytać u Franciszka Rosińskiego, kultura melanezyjska nie zna naturalnej śmierci. „Okazuje się, że krajowcom łatwiej przyjąć spowodowanie śmierci przez siły magiczne i interwencję czarodziejską, aniżeli przez przyczyny naturalne" ${ }^{\prime}$. Podobnie u Trobriandczyków - śmierć jest

${ }^{8} \mathrm{O}$ istocie czasu mitycznego i jego relacji do śmierci zob. M. Eliade, Sacrum i profanum, przeł. R. Reszke, Wydawnictwo KR, Warszawa 1999, s. 55-93.

${ }^{9}$ F.M. Rosiński, Śmierć i życie pozagrobowe według tradycyjnych wierzeń krajowców melanezyjskich, [w:] Problemy współczesnej tanatologii. Medycyna-Antropologia Kultury-Humanistyka, t. 16, red. A. Furdal, Wrocławskie Towarzystwo Naukowe, Wrocław 2012, s. 120. 
wynikiem złych magii ${ }^{10}$. Jak pisze Bronisław Malinowski: „Trobriandczycy, podobnie jak inne ludy na tym samym poziomie kultury, każdą bez wyjątku śmierć uważają za akt czarów"11. Śmierć naturalna w mentalności przedstawicieli większości kultur tradycyjnych w zasadzie nie istnieje. Można to wytłumaczyć faktem, że najczęściej giną oni w niebezpiecznych okolicznościach lub z ręki wrogich plemion, w większości nie dożywając wieku starczego.

Podsumowując, „wynika z tego, że w najdawniejszych wyobrażeniach religijnych, do których mamy dostęp, życie jest naturalne, a śmierć nienaturalna, w tym sensie, że brutalnie ingeruje w trwały porządek życia i niszczy go" ${ }^{12}$. Przekonanie, iż śmierć jest czymś nieprzystającym do rzeczywistości, przetrwało po dziś dzień nie tylko w mentalności religijnej, ale - jak się okazuje także w innych dziedzinach, czego przykładem jest medycyna.

\section{PRZYPADKOWOŚĆ ŚMIERCI W MEDYCYNIE}

W konsekwencji postępu nauki i techniki życie staje się pod wieloma względami coraz bardziej komfortowe i bezpieczne. Człowiek współczesny często uważa, że jest w stanie uniknąć wszelkich czyhających na niego zagrożeń i niebezpieczeństw. Dzięki postępowi, który można zaobserwować także w medycynie, wiele rzeczy jeszcze kilkadziesiąt lat temu niemożliwych dzisiaj stało się czymś powszechnym. Poczynając od możliwości wyko-

${ }^{10}$ Zob. B. Malinowski, Zwyczaj i zbrodnia w społeczności dzikich, [w:] tenże, Dzieła, t. 2, przeł. J. Obrębski, PWN, Warszawa 1980, s. 66-69.

${ }^{11}$ B. Malinowski, Zwyczaj i zbrodnia w społeczności dzikich, [w:] tenże, Dzieła..., S. 276.

${ }^{12}$ J. Bowker, Sens śmierci, przeł. J. Łoziński, Państwowy Instytut Wydawniczy, Warszawa 1996, s. 40-41. 
nywania trudnych i czasochłonnych operacji, przez zwiększanie szans na ratowanie zagrożonego życia, a kończąc na osiągnięciach stosunkowo młodego nurtu opieki paliatywnej, człowiek jest w stanie przedłużać i poprawiać komfort życia. Pomimo tego czasami zdarza się to, o czym wielu ludzi boi się pomyśleć: powikłania, brak lekarstw, błąd lekarski czy źle skalkulowane ryzyko.

Tanatologia, będąca jednym z działów medycyny sądowej, w sposób szczególny zajmuje się zjawiskiem śmierci. W zależności od przyczyn rozróżnia ona śmierć naturalną i gwałtowną.

Do śmierci gwałtownej dochodzi wskutek działania urazu w szerokim tego słowa znaczeniu (uraz mechaniczny, termiczny, elektryczny, chemiczny itp.). Okoliczności towarzyszące śmierci gwałtownej mogą wskazywać na zabójstwo, samobójstwo lub wypadek. [...] Śmierć gwałtowna może być powolna, poprzedzona dłużej trwającą agonią, lub nagła, bezpośrednio po zadziałaniu czynnika urazowego ${ }^{13}$.

Według powyższego śmierć przypadkowa będzie to zatem śmierć gwałtowna. Wydaje się jednak, iż na potrzeby niniejszego artykułu z definicji tej należy wykluczyć śmierć, do której doszło wskutek samobójstwa, gdyż jest ono działaniem zamierzonym i celowym.

Przytoczona definicja śmierci przypadkowej byłaby także niekompletna, jeśli pominie się taki przypadek śmierci, w którym pacjent umiera, chociaż „wszystko zostało zrobione”. Chodzi tu o śmierć, której nie da się wyjaśnić za pomocą medycznych przyczyn, gdyż według wiedzy medycznej pacjent powinien przeżyć. Podkreślić należy, że czasami nie da się jednoznacznie wyjaśnić przyczyn śmierci:

${ }^{13}$ S. Raszeja, W. Nasiłowski, J. Marksiewicz, Medycyna sądowa. Podręcznik dla studentów, Państwowy Zakład Wydawnictw Lekarskich, Warszawa 1993, s. 37. 
W przypadkach zgonów wśród niewyjaśnionych, często tajemniczych i zagadkowych okoliczności ustalenie, czy śmierć danej osoby nastąpiła z samoistnych przyczyn chorobowych, czy też była ona śmiercią gwałtowną stanowi niekiedy trudne zadanie ${ }^{14}$.

W przeciwieństwie do śmierci przypadkowej, śmierć naturalna związana jest z aspektem czasowości, z tzw. naturalnym biegiem rzeczy. Często kojarzona ze śmiercią ze starości lub z powodu długiej choroby, jest uważana za śmierć typową, „tradycyjną”. Śmierć naturalna daje umierającemu szansę na właściwe przygotowanie się do tego, co musi nastąpić. Brak takiej możliwości w wypadku śmierci, która następuje w drodze przypadku, rodzi wiele ważkich konsekwencji, zarówno tych psychologicznych, jak również prawnych.

Często „nagła śmierć” dotyka bardzo boleśnie krewnych zmarłego. Ludzi dręczy to, że:

- nie można było pożegnać się z mężem czy żoną, zamienić ostatniego słowa, po raz ostatni do siebie przemówić;

- nie było możliwości poprosić, być może raz jeszcze, o przebaczenie i darowanie czegoś lub podziękować sobie wzajemnie za coś; - pojawia się problem testamentu i ostatniej woli ${ }^{15}$.

W przypadku osób wierzących porusza się także kwestię przyjęcia sakramentów i ostatnich obrzędów religijnych, wykonywanych przy umierającym.

${ }^{14}$ J.S. Olbrycht, Wybrane przypadki z praktyki sądowo-lekarskiej: zabójstwo, samobójstwo czy nieszczéśliwy wypadek, Państwowy Zakład Wydawnictw Lekarskich, Warszawa 1964, s. 3.

${ }^{15}$ H. Nikielski, Wprowadzenie, [w:] Z pomoca umierajacym. Przyczynki do rozmowy na temat umierania $i$ śmierci, przeł. S. Szczyrbowski, Instytut Wydawniczy PAX, Warszawa 1989, s. 8. 
Zarówno więc w wypadku śmierci naturalnej, jak i przypadkowej, wyłania się szerokie pole do działania dla duchownych i terapeutów, których obowiązkiem jest udzielenie istotnych informacji bliskim osoby zmarłej i pomoc w przetrwaniu tego wyjątkowo trudnego okresu. To, w jaki sposób będą oni odbierać śmierć ukochanych osób, zależy między innymi od postawy wspomnianych specjalistów.

\section{PRZYPADKOWOŚĆ ŚMIERCI W ŚRODKACH MASOWEGO PRZEKAZU}

Ludzkie poglądy kreowane są obecnie, w dużej mierze, przez mass media. Stwierdzenie to dotyczy także przekonań na temat śmierci. Śmierć naturalna stanowi niewielką część przekazu medialnego. Zdecydowanie częściej uwagę mediów przykuwa śmierć gwałtowna, najczęściej brutalna, będąca efektem przemocy czy katastrofy. Powodem jest fakt, iż „panująca ideologia jest [...] zainteresowana $w$ ukazywaniu śmierci jako fatum, nieszczęśliwego przypadku"16 ${ }^{16}$. Zwróćmy uwagę na trzy typy przekazu medialnego: a) serwisy informacyjne, b) reklamy, c) filmy; odpowiednio w kontekście tragicznym, edukacyjnym i rozrywkowym ${ }^{17}$.

Śmierć przypadkowa $\mathrm{w}$ sensie tragicznym jest najczęstszym rodzajem śmierci przedstawianej $\mathrm{w}$ radiowych i telewizyjnych serwisach informacyjnych. Obraz śmierci jest tu prezentowany w specyficzny sposób tak, aby jak najdłużej został w ludzkiej pamięci, pobudził do spekulacji i wywołał uczucie empatii. Nie

${ }^{16}$ G. Lenne, Śmierć $w$ kinie, przeł. T. Szczepański, [w:] Wymiary śmierci, red. D. Dmochowska, T. Swoboda, słowo/obraz terytoria, Gdańsk 2002, s. 224.

${ }^{17}$ Zob. M. Tomiczek, Tragizm, rozrywka, edukacja - różne obrazy śmierci w mediach jako próba przekroczenia tabu śmierci i umierania, [w:] Media wobec śmierci, t. 2, red. A. Gralczyk, M. Laskowska, P. Drzewiecki, Dom Wydawniczy Elipsa, Warszawa 2012, s. 17-28. 
wszystkie informacje o zdarzeniu zostają ujawnione, a sposób przekazu informacji budzi zainteresowanie i wątpliwości. O śmierci przypadkowej mówi się najczęściej w kontekście katastrof, wojen, wypadków. Obrazy te, przyciągając uwagę odbiorców, zadomawiają się na dobre w ich życiu i towarzyszą im każdego dnia.

W aspekcie edukacyjnym śmierć przypadkowa pojawia się w kampaniach społecznych i jest traktowana na poważnie ${ }^{18}$. Przekaz tych kampanii jest w pewnym sensie próbą uwrażliwienia ludzi na cierpienie i przygotowania ich na śmierć, która jest zjawiskiem powszechnym. Istotne jest to, żeby zdawać sobie sprawę z konsekwencji własnych czynów, być świadomym własnych emocji na myśl o śmierci, wypracować własne podejście do śmierci, w szczególności tej nieprzewidzianej.

Dotychczas uważano, że w reklamie nie powinno się mówić o śmierci. Nie pasowała ona do świata wykreowanego przez twórców reklam. Współczesnego widza nie zadawala jednak takie wyidealizowane przedstawienie rzeczywistości, dlatego reklama, aby przyciągnąć uwagę odbiorcy, musi budzić silne emocje i szokować, zachowując jednocześnie wymiar rozrywkowy. Śmierć „przez przypadek” jest traktowana w reklamie z przymrużeniem oka, a często nawet prześmiewczo. Przykładem jest spot reklamowy sklepu Ikea ${ }^{19}$, której hasło przewodnie brzmi: Posprzątaj,jeśli nie dla siebie to dla innych. W reklamie tej śmierć jest wynikiem przypadku, zaniedbania, głupoty, która została przestawiona

${ }^{18}$ Przykładem jest kampania społeczna pod nazwą Użyj wyobraźni, której głównym przekazem jest uświadomienie ludziom młodym, ale nie tylko, że każdy czyn ma swoje konsekwencje i trzeba być odpowiedzialnym za wszystko, co się robi, ponieważ śmierć jest równie realna, jak życie. Zob. w internecie: http://www.youtube.com/watch?v=k4-MdswqO9k (dostęp: 12 XII 2012).

${ }^{19}$ Zob. w internecie: http://www.talenty.pl/index.php?str=linkif\&filmy= 10056 (dostęp: 12 XII 2012). 
w sposób wręcz cyniczny. W przypadku wymienionej powyżej reklamy bodźcem przyciągającym uwage ma być czynnik zmysłowy. „Skłonność do łączenia aktywności seksualnej człowieka i jego śmierci nie stanowi wszak novum w kulturze. Obie budzą ciekawość, kontrowersje, są źródłem lęków i niepokojów..."20.

Śmierć jest również problemem dla twórców kina. Widzowi łatwo uwierzyć w realność fabuły, ale nie w rzeczywistą śmierć aktorów. „W kinie można pokazać wszystko - oprócz śmierci”21. Śmierć na ekranie zawsze jest „na niby”, a jednak wciąż jest przedstawiana. Do zobrazowania śmierci ukazanej w filmie, która ma charakter przypadkowy, posłuży krótkometrażowa ekranizacja pt.: Cukier (Suiker) w reżyserii Jeroen Annokee. Tytułowy cukier jest filmowym motywem spotkania dwojga ludzi, którzy umierają w ciągu następnych kilku minut. „Biała śmierć” jest pretekstem do ukazania przypadkowości śmierci, która w tym wypadku jest niczym innym, jak wynikiem nieuważnego działania i splotu nieoczekiwanych wydarzeń. Ta absurdalna śmierć dwojga ludzi wywołuje $u$ odbiorcy mieszane uczucia. $Z$ jednej strony prowokuje śmiech, z drugiej sprawia wrażenie śmierci udawanej, odrealnionej. Szokuje, a zarazem skłania do współczucia. Jej groteskowość jest esencją tego filmu aż do ostatniej sceny.

Jak już zostało wspomniane, naturalna śmierć jest „niemedialna” i dlatego zajmuje niewielką ilość czasu antenowego. W serwisach informacyjnych wspomina się o niej jedynie w kontekście społecznym lub w przypadku, gdy umiera osoba znana i poważana w szerszych kręgach. $\mathrm{Z}$ reguły śmierć naturalna nie budzi silnych

${ }^{20}$ B. Wolek-Kocur, Eros $i$ Tanatos $w$ stużbie reklamy, [w:] Media wobec śmierci, t. 1, red. K. Kwasik, J. Jaroszyński, G. Łęcicki, Dom Wydawniczy Elipsa, Warszawa 2012, s. 252.

${ }^{21}$ G. Lenne, Śmierć w kinie, przeł. T. Szczepański, [w:] Wymiary..., s. 219. 
emocji i nie jest spektakularna. W reklamie tego typu śmierć nie pasuje do przyjętej konwencji (z jednej strony do wizerunku doskonałego, wiecznego wręcz życia, z drugiej do przedstawienia śmierci w celu wywołania skrajnych emocji), w filmie stanowi tematykę poboczną, towarzyszącą innym wydarzeniom. Obraz śmierci przypadkowej przedstawiony na szklanym ekranie różni się od tej, która ma miejsce w rzeczywistości.

Informacyjny obraz medialny dotyczy wprawdzie realnych wydarzeń, ale dociera do widza w różnym czasie i miejscu. Powoduje to, że odbiorca funkcjonuje $\mathrm{w}$ dwóch równoległych wymiarach: rzeczywistym oraz medialnym, pomiędzy którymi przemieszcza się swobodnie i płynnie, ale również bezpiecznie ${ }^{22}$.

\section{ZAKOŃCZENIE}

Przypadek jest dla współczesnej humanistyki kategorią niezmiernie ważną. Jego wykładnia już dawno straciła jednoznaczny związek z naukami ścisłymi i obecnie sytuuje się w centrum myśli humanistycznej ${ }^{23}$.

Przypadek jest wpisany w ludzką egzystencję, ale zaskakuje za każdym razem, gdy się przytrafi. Widoczny w każdej dziedzinie życia, wkradł się na dobre także do koncepcji śmierci. Sprawił, że dziedzina, która trudno poddaje się analizie naukowej, stała się jeszcze bardziej niezrozumiała. Oprócz aspektu irracjonalności, przypadkowość nadaje śmierci cechę (nie)konieczności, nieprzewidywalności, gwałtowności i chaotyczności.

${ }^{22}$ M. Tomiczek, Tragizm, rozrywka, edukacja - różne obrazy śmierci w mediach jako próba przekroczenia tabu śmierci i umierania, [w:] Media..., s. 23.

${ }^{23}$ R. Koschany, Przypadek. Kategoria egzystencjalna $i$ artystyczna $w$ literaturze i filmie, Wydawnictwo Uniwersytetu Wrocławskiego, Wrocław 2006, s. 8. 
Śmierć, podobnie jak przypadek, jest zagadnieniem interdyscyplinarnym. Czytelnika nie powinno więc dziwić, że w niniejszym artykule zostały poruszone różne aspekty przypadkowej śmierci, jej pochodzenie, odbiór i przekaz. Każde w wymienionych ujęć zostało tutaj jedynie naszkicowane i domaga się szerszego omówienia, co jest zachętą do dalszych badań.

Większość ludzi umiera w sposób naturalny na skutek starzenia się lub choroby. Niektórzy umierają nieoczekiwanie, gdy serce lub płuca nagle odmówią posłuszeństwa. Niektóre osoby stają się ofiarami wypadków i morderstw ${ }^{24}$. Wydaje się, że odeszły za szybko i jakby nie w porę. Jak można przeczytać w motcie do niniejszego artykułu, także Simone de Beauvoir nie zgadza się z pojęciem śmierci naturalnej. Każda śmierć jest dla niej nieoczekiwana i mimo, że jest zjawiskiem powszechnym, zawsze jest precedensem. Jak pisze Vladimir Jankelevitch:

Śmierć to wydarzenie gwałtowne, brutalne, nagłe. Zawsze. Nawet zgon sędziwego starca o zwapniałych żyłach, pozbawionego odporności jest wypadkiem. Kiedy dziarski, pełen życia młodzieniec wpada pod autobus, mamy do czynienia ze śmiercią gwałtowną, tragiczną. To samo można jednak powiedzieć o śmierci staruszka, który złapał jakąś infekcję i umiera we własnym łóżku. Ta śmierć mogłaby się nie wydarzyć w tym konkretnym momencie ${ }^{25}$.

Nie da się ukryć, że nawet ludzie przygotowani na śmierć i pogodzeni z własnym losem w obliczu śmierci skłonni są „targować się" o jeszcze jeden dzień życia.

${ }^{24}$ Zob. B. Innes, Granice śmierci, przeł. M. Bernacki, E. Krzak-Ćwiertnia, Bellona, Warszawa 1999, s. 37.

${ }^{25} \mathrm{~V}$. Jankelevitch, To, co nieuchronne. Rozmowy o śmierci, przeł. M. Kwaterko, Państwowy Instytut Wydawniczy, Warszawa 2005, s. 101. 


\section{THE FORTUITY OF DEATH \\ (SELECTED ASPECTS)}

\section{SUMMARY}

The fortuity can be defined both as an unpredictable case and a fate or destiny. This article will show that ambivalence of meaning on the example of phenomenon of death. The article contains three parts. The first one tells about the meaning of the fortuity of death in some archaic cultures. The next one refers to the case of the fortuity of death in medicine and its consequences. However, the last part brings up the way of presenting the fortuity of death in mass media and its influence on recipients.

\section{KEYWORDS}

fortuity, fortuity and natural death, study of religions, medicine, mass media, philosophy of death 